\title{
Soil carbon research and global environmental challenges
}

\section{Working Paper}

\section{Author(s):}

Hartemink, Alfred E.; Lal, Rattan; Gerzabek, Martin H.; Jama, Bashir; McBratney, Alex; Six, Johan; Tornquist, Carlos G.

Publication date:

2014-04-21

Permanent link:

https://doi.org/10.3929/ethz-b-000093882

\section{Rights / license:}

Creative Commons Attribution 4.0 International

\section{Originally published in:}

PeerJ Preprints 2, https://doi.org/10.7287/peerj.preprints.366v1 


\title{
1 Soil carbon research and global 2 environmental challenges \\ 3
}

4

5

6

7

\author{
Alfred E. Hartemink ${ }^{1}$, Rattan Lal ${ }^{2}$, Martin H. Gerzabek ${ }^{3}$, Bashir Jama ${ }^{4}$, Alex B. McBratney ${ }^{5}$, \\ Johan Six ${ }^{6}$, C. Gustavo Tornquist ${ }^{7}$ \\ 1 University of Wisconsin - Madison, Department of Soil Science, FD Hole Soils Lab, 1525 Observatory Drive, Madison, WI \\ 53706 USA. E-mail: hartemink@wisc.edu (corresponding author) \\ 2 Carbon Management and Sequestration Center, The Ohio State University, Columbus, OH 43210 USA. E-mail: lal.1@osu.edu \\ 3 Institute for Soil Research, University of Natural Resources and Life Sciences Vienna, Peter-Jordan-Strasse 82, A-1190 Vienna, \\ Austria. E-mail: martin.gerzabek@boku.ac.at \\ 4 AGRA, CISR Office Complex, PMB KIA 114, Accra, Ghana. E-mail BJama@agra.org \\ 5 Faculty of Agriculture and Environment, The University of Sydney NSW 2006. Australia. E-mail: \\ Alex.McBratney@sydney.edu.au \\ 6 Department of Environmental Systems Science, Swiss Federal Institute of Technology, ETH-Zurich, Tannenstrasse 1, 8092 \\ Zurich, Switzerland. E-Mail: jsix@ethz.ch \\ 7 UFRGS - Universidade Federal do Rio Grande do Sul, Porto Alegre, RS, Brazil. E-mail: carlos.tornquist@ufrgs.br
}

The role of soil organic carbon $(\mathrm{SOC})$ in maintaining soil conditions and its resulting services is well established. Currently, over 1,000 articles per year are being published in peer-reviewed journals, and increasing at about $10 \%$ per year. It was not until the 1980s when the relation between soils and climate change was noted, and it was realized that soils play a key role as a sink and source of greenhouse gases (GHGs) (Bouwman 1990, Scharpenseel, Ayoub and Schomaker 1990, Jenny 1980). A large number of research projects have been initiated globally in which soil C is a key component, and there have been some excellent reviews (Lal 2004, Stockmann et al. 2013, Melillo et al. 2011). Yet, there is a lack of focus in soil $\mathrm{C}$ research in relation to current environmental challenges. Here we recommend research priorities to advance the knowledge base and use of soil C in relation to global human and environmental challenges: food and fiber production, water scarcity and purification, energy production, climate change, biodiversity, recycling waste, and environmental degradation. We have listed the priorities under three themes: (i) Soil C in space and time, (ii) Soil C properties and processes, and (ii) Soil C depletion and management.

\section{Soil $C$ in space and time}

Compared with other environmental components, soils are some of the most variable across space and time and much understanding has been gained in the past decades about what causes variation and 
how it can be modeled. Variation in soil types partly explains variation in SOC concentrations and pools (Batjes 1996), and the diverse range of factors that affect their magnitude and dynamics. Researchable challenges in this theme include: measurement and monitoring across the landscape scale, depth distribution of SOC in relation to land use and management, and up scaling from point scale to landscapes, watersheds and larger extents (Minasny et al. 2013).

Monitoring of SOC across landscape units and over time is crucial for the assessment of spatial and temporal variations in SOC pools and fluxes. Such monitoring programs should be carefully designed and once started should be conducted in the long-term (e.g. over a generation or more). Data from the Critical Zone Observatory Networks (Banwart et al. 2012), the Long Term Ecological Research Networks (LTER), and the Deep Carbon Observatory are promising for a comprehensive assessment of changes in SOC over time and space. Considerable amount of data are also available from classic field experimentations that have been conducted in the past 200 years (Leigh and Johnston 1994).

There is a need for developing time effective, accurate and comparable measurements of SOC, specifically for large sample numbers for monitoring and modeling purposes. Increasing the speed of measurements and taking into account spatial variability of SOC contents and soil bulk density are important research topics. Methods of sampling and analyses need standardization but also further refinement. There is a set of proximal soil sensing technologies available by which the number of measurements can be greatly increased while considerably reducing the time and cost per observation (McBratney, Minasny and Viscarra Rossel 2006). The magnitude of soil C needs to be expressed on mass per volume basis and not solely in mass concentrations (Lee et al. 2010). Bulk density measurements are relatively easy to take but data availability is limited.

Many soils have large pools of SOC below the topsoil or surface horizon. This SOC may have been buried, such as in volcanic or alluvial soils, or may have been deposited into the subsoil over time. Although the concentrations of SOC at depth may be small, the sheer volume contributes to a considerable pool that has not been well-quantified (Lorenz and Lal 2005) because it is variable across space (Kravchenko and Robertson 2011) and the temporal dynamics are not well understood (Van Oost et al. 2012). Also the contribution of inorganic $C$ as secondary carbonates to $C$ sequestration potential should be further investigated and quantified (Schlesinger 1999).

Changes in SOC pools are rapid in areas where antecedent stocks are large. These areas, the 67 (Mollisols) of Russia and North America, and soils of some tropical biomes (e.g. tropical rainforest, acid 68 savannas). The changing climate and the attendant increased decomposition warrant the need for 
monitoring and assessing $\mathrm{C}$ pools in these hot spots. Priority areas for SOC research also include those that are subject to rapid land use change, changes in climate, areas from which we have only sparse data, and soils of ecologically-sensitive regions like many of the peat areas in the world.

\section{Soil C properties and processes}

Soil organic $C$ is one of the key drivers of rhizosphere and bulk soil processes and its functions. It influences adsorption, $\mathrm{pH}$ buffering, heat absorption, nutrient retention, soil structure and its stability, infiltration, water storage and is the most important substrate for soil organisms. Current research activities put considerable emphasis on C sequestration and SOC dynamics but less on its functions and provisioning of essential ecosystem services (e.g., climate change adaptation and mitigation, food and nutritional security, water purification and renewal). Further investigation is needed on the interaction of SOC with mineral surfaces in soils, and on the effect of clay mineralogy on SOC sequestration by the build-up of microaggregates (Tisdall and Oades 1982). Biological processes affecting SOC stabilization and turnover also need further attention. The role of roots in relation to recalcitrant SOC, fungal contribution to $\mathrm{SOC}$ sequestration, and functional biodiversity need to be further quantified (Henning et al. 1996, Pendall and King 2007).

Soil erosion might modify soil respiration which affects local, regional and even global C balances. The fate of SOC transported by erosional processes (water and wind) is a theme which needs to be studied by interdisciplinary teams at watershed scales (Van Oost et al. 2007). Formation of secondary carbonates in soils of arid and semiarid regions, and leaching of bicarbonates in irrigated soils is relevant to SOC dynamics (Schlesinger 1999). Secondary carbonates play a major role in soil C dynamics in Mollisols, Vertisols, and Aridisols, and the application of liming materials, cement and C-rich by-products can affect the formation of secondary carbonates.

Understanding SOC behavior in soils involves the molecular scale (properties of organic molecules and their molecular interaction with soil minerals) as well as the micro-scale (formation of micro-aggregates, physical protection of SOM, interaction of micro-organisms and their impact on surface properties). Combining information across different scales is a challenge, for example, combining remote sensing data with plot information as a basis for modeling on the landscape level, or combining molecular information with micro-and macro-structural data to elucidate the accessibility of reactive surfaces. 


\section{Soil $\mathrm{C}$ depletion and management}

The management of SOC is essential for sustaining food production (Bauer and Black 1994) but many soils of agroecosystems have been depleted of their antecedent SOC pool. There is a need to replenish SOC to above a critical level depending on the soil type, climate and ecosystem. Key research questions in raising SOC levels are the use efficiency of inputs (fertilizer, water etc.), gains in biomass productivity per unit increase in SOC pool, and the impact of management on the rate of change in the SOC pool of the root zone. The impact of no-till (NT) farming or conservation agriculture, especially with regard to depth distribution of SOC pool and impact of residue management and its placement in the soil, need to be researched under site-specific conditions. There are several technologies that can be used to potentially increase the SOC pool (NT, mulch, cover crops, agroforestry, deep-rooted species, biochar, etc.) and the choice of specific techniques depends on biophysical, social and economic factors. Whereas the adoption of conservation agriculture is useful in soils prone to erosion, not all soils are suitable for it, and there are also constraints to its adoption by resource-poor land holders in developing countries (Chivenge et al. 2007). Competing uses of crop residues (e.g., feed, fodder, fencing and construction material, cooking fuel) are major considerations.

Trading of soil C credits or farming soil C could create another income stream for the resourcepoor farmers, and promote the adoption of best management practices which restore the depleted soil

C pool, enhance soil systems functioning and strengthen provisioning of essential ecosystem services. In this context, a protocol must be developed to trade $\mathrm{C}$ credits in voluntary or regulatory markets using a fair price of soil $\mathrm{C}$ based on its true societal value. The latter must be based on incremental increase in essential ecosystem services provisioned by sequestration of atmospheric $\mathrm{CO}_{2}$ in the soil.

Table 1 lists the priorities for soil $C$ research and its link to the main global environmental challenges identified for soil science (McBratney, Field and Koch 2013, Hartemink 2008, Janzen et al. 2011).

$<$ Table 1 somewhere here> currently lacking in part because data on soil information is not readily available or compatible with model needs, and in part because the climate-modeling community is not well-linked to the soil science community. This has improved in recent years (Arrouays et al. 2014) but there remains scope for increased interaction and cooperation. There may also be scope for linkages to other disciplines and the 
microbial ecology community is such an example. Microbes strongly influence processes underpinning $C$ models, and their activity is largely influenced by soil conditions.

\section{References}

Arrouays, D., M. G. Grundy, A. E. Hartemink, J. Hempel, G. B. M. Heuvelink, S. Y. Hong, P. Lagacherie, G. Lelyk, A. B. McBratney, N. J. McKenzie, M. L. Mendonça Santos, B. Minasny, L. Montanarella, I. O. A. Odeh, P. A. Sanchez, J. A. Thompson \& G. L. Zhang (2014) GlobalSoilMap: toward a fineresolution global grid of soil properties. Advances in Agronomy, (in the press).

Banwart, S., M. Menon, S. M. Bernasconi, J. Bloem, W. E. H. Blum, D. M. de Souza, B. Davidsdotir, C. Duffy, G. J. Lair, P. Kram, A. Lamacova, L. Lundin, N. P. Nikolaidis, M. Novak, P. Panagos, K. V. Ragnarsdottir, B. Reynolds, D. Robinson, S. Rousseva, P. de Ruiter, P. van Gaans, L. P. Weng, T. White \& B. Zhang (2012) Soil processes and functions across an international network of Critical Zone Observatories: Introduction to experimental methods and initial results. Comptes Rendus Geoscience, 344, 758-772.

Batjes, N. H. (1996) Total Carbon and Nitrogen in the Soils of the World. European Journal of Soil Science, 47, 151-163.

Bauer, A. \& A. L. Black (1994) Quantification of the Effect of Soil Organic Matter Content on Soil Productivity. Soil Sci. Soc. Am. J., 58, 185-193.

Bouwman, A. F. 1990. Soils and the greenhouse effect. Chichester: John Wiley.

Chivenge, P. P., H. K. Murwira, K. E. Giller, P. Mapfumo \& J. Six (2007) Long-term impact of reduced tillage and residue management on soil carbon stabilization: Implications for conservation agriculture on contrasting soils. Soil \& Tillage Research, 94, 328-337.

Hartemink, A. E. (2008) Soils are back on the global agenda. Soil Use \& Management, 24, 327-330.

Henning, F. P., C. W. Wood, H. H. Rogers, G. B. Runion \& S. A. Prior (1996) Composition and decomposition of soybean and sorghum tissues grown under elevated atmospheric carbon dioxide. Journal of Environmental Quality, 25, 822-827.

Janzen, H. H., P. E. Fixen, A. J. Franzluebbers, J. Hattey, R. C. Izaurralde, Q. M. Ketterings, D. A. Lobb \& W. H. Schlesinger (2011) Global Prospects Rooted in Soil Science. Soil Science Society of America Journal, 75, 1-8.

Jenny, H. (1980) Alcohol or Humus. Science, 209, 444-444.

Kravchenko, A. N. \& G. P. Robertson (2011) Whole-Profile Soil Carbon Stocks: The Danger of Assuming Too Much from Analyses of Too Little. Soil Science Society of America Journal, 75, 235-240.

Lal, R. (2004) Soil carbon sequestration to mitigate climate change. Geoderma, 123, 1-22.

Lee, J., J. W. Hopmans, D. E. Rolston, S. G. Baer \& J. Six (2010) Determining soil carbon stock changes: Simple bulk density corrections fail (vol 134, pg 251, 2009). Agriculture Ecosystems \& Environment, 138, 355-355.

Leigh, R. A. \& A. E. Johnston. 1994. Long-term experiments in agricultural and ecological sciences. Wallingford: $C A B$ International.

Lorenz, K. \& R. Lal (2005) The Depth Distribution of Soil Organic Carbon in Relation to Land Use and Management and the Potential of Carbon Sequestration in Subsoil Horizons. Advances in Agronomy, 88, 35-66.

McBratney, A. B., D. J. Field \& A. Koch (2013) The dimensions of soil security. Geoderma, 213, 203-213.

McBratney, A. B., B. Minasny \& R. Viscarra Rossel (2006) Spectral soil analysis and inference systems: A powerful combination for solving the soil data crisis. Geoderma, 136, 272-278.

Melillo, J. M., S. Butler, J. Johnson, J. Mohan, P. Steudler, H. Lux, E. Burrows, F. Bowles, R. Smith, L. Scott, C. Vario, T. Hill, A. Burton, Y. M. Zhou \& J. Tang (2011) Soil warming, carbon-nitrogen 
interactions, and forest carbon budgets. Proceedings of the National Academy of Sciences of the United States of America, 108, 9508-9512.

Minasny, B., A. B. McBratney, B. P. Malone \& I. Wheeler (2013) Digital Mapping of Soil Carbon. Advances in Agronomy, Vol 118, 118, 1-47.

Pendall, E. \& J. Y. King (2007) Soil organic matter dynamics in grassland soils under elevated CO2: Insights from long-term incubations and stable isotopes. Soil Biology \& Biochemistry, 39, 26282639.

Scharpenseel, H. W., A. Ayoub \& M. Schomaker. 1990. Soils on a warmer earth: effects of expected climate change on soil processes, with emphasis on the tropics and sub-tropics. Amsterdam: Elsevier.

Schlesinger, W. H. (1999) Carbon and agriculture - Carbon sequestration in soils. Science, 284, 2095. Stockmann, U., M. A. Adams, J. W. Crawford, D. J. Field, N. Henakaarchchi, M. Jenkins, B. Minasny, A. B. McBratney, V. D. de Courcelles, K. Singh, I. Wheeler, L. Abbott, D. A. Angers, J. Baldock, M. Bird, P. C. Brookes, C. Chenu, J. D. Jastrowh, R. Lal, J. Lehmann, A. G. O'Donnell, W. J. Parton, D. Whitehead \& M. Zimmermann (2013) The knowns, known unknowns and unknowns of sequestration of soil organic carbon. Agriculture Ecosystems \& Environment, 164, 80-99.

Tisdall, J. M. \& J. M. Oades (1982) Organic matter and water-stable aggregates in soils. Journal of Soil Science, 33, 141-163.

Van Oost, K., T. A. Quine, G. Govers, S. De Gryze, J. Six, J. W. Harden, J. C. Ritchie, G. W. McCarty, G. Heckrath, C. Kosmas, J. V. Giraldez, J. R. M. da Silva \& R. Merckx (2007) The impact of agricultural soil erosion on the global carbon cycle. Science, 318, 626-629.

Van Oost, K., G. Verstraeten, S. Doetterl, B. Notebaert, F. Wiaux, N. Broothaerts \& J. Six (2012) Legacy of human-induced $\mathrm{C}$ erosion and burial on soil-atmosphere $\mathrm{C}$ exchange. Proceedings of the National Academy of Sciences of the United States of America, 109, 19492-19497. 
Table 1. Priorities for soil $\mathrm{C}$ research, and its relevance to global environmental challenges and ecosystem services (1: food and fibre production; 2 : water scarcity and purification; 3: energy production; 4: climate change; 5: biodiversity; 6: recycling waste; 7: environmental degradation)

\begin{tabular}{|c|c|c|}
\hline Main research area & Topics & Global environmental challenge \\
\hline \multirow[t]{8}{*}{ Soil C in space \& time } & Monitoring and assessment of $\mathrm{C}$ stocks and fluxes & $1-7$ \\
\hline & Standardizing sampling methods & $1-7$ \\
\hline & Development of proximal soil sensors for $\mathrm{C}$ analysis & $1-7$ \\
\hline & Assessment of SOC at depths below the topsoil & $4,6,7$ \\
\hline & Contribution of soil inorganic $\mathrm{C}$ to $\mathrm{C}$ sequestration potential & 4 \\
\hline & Upscaling from pedon and field measurements to regional, national and contintental scales & $1-7$ \\
\hline & Increased reporting of uncertainties in measurement, monitoring and modeling of $\mathrm{SOC}$ & $1-7$ \\
\hline & $\begin{array}{l}\text { Establish list of priority areas that need research: areas of rapid land use change, areas with large } C \text { stocks and a rapidly changing climate, } \\
\text { areas for which there exists only sparse data or high uncertainties, and ecologically sensitive ecoregions and global hot spots }\end{array}$ & $1-7$ \\
\hline \multirow[t]{9}{*}{ Soil C properties \& processes } & Development of time effective, accurate SOC measurement apparatus such as inelastic neutron scattering and laser induced breakdown & 5 \\
\hline & Increase understanding about $\mathrm{C}$ interaction with $\mathrm{Al}$ and $\mathrm{Fe}$ and the impact of redox chemistry & $2,6,7$ \\
\hline & Interaction between SOC and mineral surfaces and formation of stable microaggregates & 1,4 \\
\hline & Contribution of black carbon to recalcitrant SOC fractions & 4 \\
\hline & Hydrophobicity and SOC & 1,2 \\
\hline & Quantitative contribution of micro-, meso-, and macro- fauna on SOC turnover, and the role of microbial biomass C & $4,5,7$ \\
\hline & Role of soil structure in SOC sequestration and modeling & $1,2,4,7$ \\
\hline & The role of fungi in $\mathrm{C}$ sequestration & $4,5,6$ \\
\hline & Threshold level of SOC in the root zone in relation to rhizospheric processes & $1,5,6$ \\
\hline \multirow[t]{3}{*}{ Soil C depletion \& management } & Sequestration of SOC in deltas and oceans & 2,4 \\
\hline & The fate of $\mathrm{C}$ transported by erosion & $1,4,7$ \\
\hline & The effects of fire on SOC in relation to hydrophobicity and black carbon & 2 \\
\hline
\end{tabular}


Climate resilience of soils of agroecosystems and SOC pool in relation to drought 